\title{
Molecular regulation of copper excretion in the liver
}

\author{
Cisca Wijmenga and Leo W. J. Klomp \\ Department of Biomedical Genetics, University Medical Center, Stratenum 2.117, Universiteitsweg 100, \\ 3584 CG Utrecht, The Netherlands
}

\begin{abstract}
$\mathrm{Cu}$ is an essential nutrient that is required for a broad range of cellular and molecular processes. Mammals have efficient systems to control $\mathrm{Cu}$ homeostasis that operate at the level of controlling uptake, distribution, sequestration and excretion of $\mathrm{Cu}$. The study of diseases associated with disturbed $\mathrm{Cu}$ homeostasis has greatly enhanced our understanding of the molecular mechanisms involved in $\mathrm{Cu}$ metabolism. In man the liver is responsible for excreting excess $\mathrm{Cu}$ from the body by means of biliary secretion. Wilson disease is a severe human disorder characterized by $\mathrm{Cu}$ accumulation in the liver as a result of a deficiency in biliary $\mathrm{Cu}$ secretion. This disorder is caused by mutations in the gene that encodes a $\mathrm{Cu}$-transporting P-type ATPase (ATP7B). The MURR1 gene was identified recently, and it was hypothesized that this gene is also essential for biliary $\mathrm{Cu}$ excretion and is presumed to act downstream of ATP7B. MURR1 is mutated in canine $\mathrm{Cu}$ toxicosis, a disorder with phenotypic characteristics similar to those of Wilson disease. MURR1 encodes a protein that is of unknown function and is without detectable sequence homology to known proteins. MURR1 is readily detected in all tissues and cell types, suggesting that it may exhibit a pleiotropic function in different organs, which may or may not be exclusively linked to $\mathrm{Cu}$ homeostasis. The use of genetic, biochemical and genomic tools, as well as the development of appropriate models in organisms other than dog, will allow the elucidation of the molecular and cellular function of MURR1 in relation to hepatic $\mathrm{Cu}$ homeostasis and biliary $\mathrm{Cu}$ excretion.
\end{abstract}

Copper metabolism: Biliary excretion: MURR1

A balanced diet contains adequate amounts of protein, carbohydrates, fat, vitamins and minerals, including trace metals. Trace metals can be essential (e.g. Fe, $\mathrm{Zn}, \mathrm{Cu}$ and $\mathrm{Mn}$ ) or non-essential (e.g. $\mathrm{Pb}$ and $\mathrm{Hg}$ ). Non-essential trace metals can be toxic to life, even in extremely small quantities. In contrast, the essential trace metals sustain important biological functions, although excess amounts can also be toxic. Homeostatic control is defined as the balance between essentiality and toxicity, and it is maintained by various mechanisms, including uptake, transport, storage and excretion of metals.

$\mathrm{Cu}$ is one of the essential trace metals for all organisms, including man. $\mathrm{Cu}$ can exist in two redox states, which renders it an essential component of the active site of a number of cupro-enzymes, e.g. the cytochrome $\mathrm{C}$ oxidase complex, a component of the mitochondrial electron transport chain that plays an essential role in cellular respiration. $\mathrm{Cu}$ also forms the catalytic component of $\mathrm{Cu} / \mathrm{Zn}$ superoxide dismutase, which protects against free radicals.
Paradoxically, this same property can also make $\mathrm{Cu}$ toxic when present in excess, because it is thought to lead to the formation of reactive oxygen species through Fenton chemistry. Free $\mathrm{Cu}$ ions can associate with adventitious sites, thereby impairing normal cellular function.

Recent developments and novel prospects in the understanding of the homeostatic control of $\mathrm{Cu}$ will be addressed. The recent exciting discovery of MURRl as a $\mathrm{Cu}$-homeostasis gene and the role of MURR1 in the regulation of biliary $\mathrm{Cu}$ excretion will be used as a recurrent theme to outline new genetic, genomic, proteomic and cell biological approaches to further our understanding of the regulation of $\mathrm{Cu}$ metabolism in general.

\section{Copper}

To maintain its essential functions, it is important that there is a sufficient daily intake of $\mathrm{Cu}$ in the diet. $\mathrm{Cu}$ is 


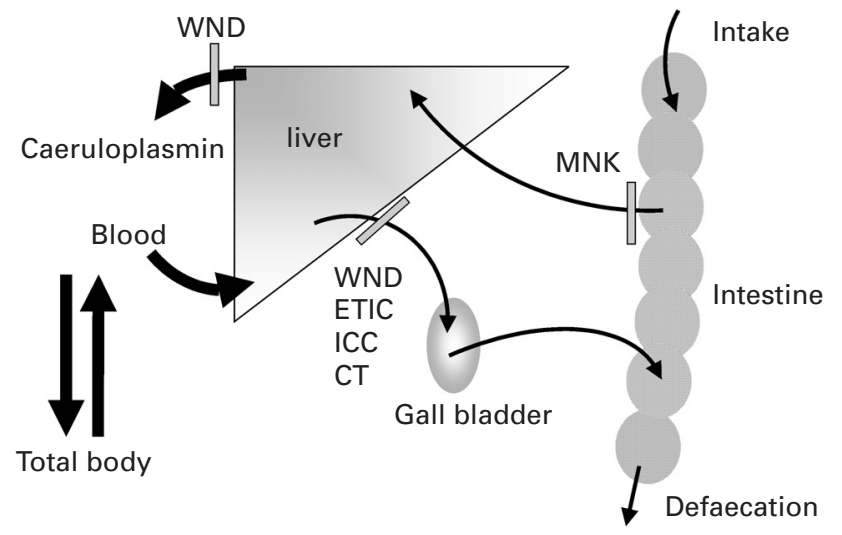

Fig. 1. Physiology of copper homeostasis. Schematic representation of organs involved in copper intake, redistribution and excretion; for further explanation, see p. 33. [, Processes disturbed by specific monogenic copper homeostasis disorders. MNK, Menkes disease; WND, Wilson disease; ETIC, endemic Tyrolean infantile cirrhosis; ICC, Indian childhood cirrhosis; CT, canine copper toxicosis.

found in a wide variety of foods, including cereals, meat, fruits and vegetables. Drinking water can also be a major source of $\mathrm{Cu}$ intake, especially when $\mathrm{Cu}$ water pipes are corroded. The acceptable range of oral intake of $\mathrm{Cu}$ is between 1.3 and $13 \mathrm{mg} \mathrm{Cu} / \mathrm{d}$ for adults, and between 0.6 and $1 \mathrm{mg} \mathrm{Cu} / \mathrm{d}$ for children. A schematic representation of the regulation of human $\mathrm{Cu}$ metabolism is presented in Fig. 1.

Approximately $15 \%$ of the $\mathrm{Cu}$ taken up from the diet is transported to various tissues, while the remaining $85 \%$ of the $\mathrm{Cu}$ is excreted. Under normal physiological conditions about $98 \%$ of the $\mathrm{Cu}$ excretion is via the bile and only $2 \%$ via the urine, indicating that the liver is the organ in which whole-body $\mathrm{Cu}$ homeostasis is achieved by regulation of biliary excretion. Dietary $\mathrm{Cu}$ is absorbed across the mucosal membrane of the upper intestine and transported to the rest of the body. $\mathrm{Cu}$ enters the bloodstream, where it binds to proteins or amino acids; thereafter $\mathrm{Cu}$ leaves the blood and enters the liver and kidneys. The liver takes up the majority of the $\mathrm{Cu}$ present in the circulation. $\mathrm{Cu}$ may enter the hepatocyte by means of $\mathrm{Cu}$ transporter 1 (CTR1), after which it is distributed intracellularly into one of three pathways by the $\mathrm{Cu}$ chaperones cytochrome C oxidase assembly factor 17 (COX17), ATOX1 and $\mathrm{Cu}$ chaperone for superoxide dismutase 1 (CCS1) for incorporation into cytochrome $\mathrm{C}$ oxidase, $\mathrm{Cu}$-transporting P-type ATPase (ATP7B) and $\mathrm{Cu} / \mathrm{Zn}$ superoxide dismutase respectively (Fig. 2). The cellular function of the $\mathrm{Cu}$ chaperone ATOX1 will be discussed in more detail later (see p. 33). Since there is virtually no free $\mathrm{Cu}$ available in the hepatocyte, any excess $\mathrm{Cu}$ is bound to metallothioneins, which act as scavengers. Our knowledge of the general mechanisms of cellular $\mathrm{Cu}$ homeostasis forms the foundation of our understanding of the role of the liver in whole-body $\mathrm{Cu}$ homeostasis. The characterization of $\mathrm{Cu}$ metabolism in the yeast Saccharomyces cerevisiae and other model organisms has contributed much to our

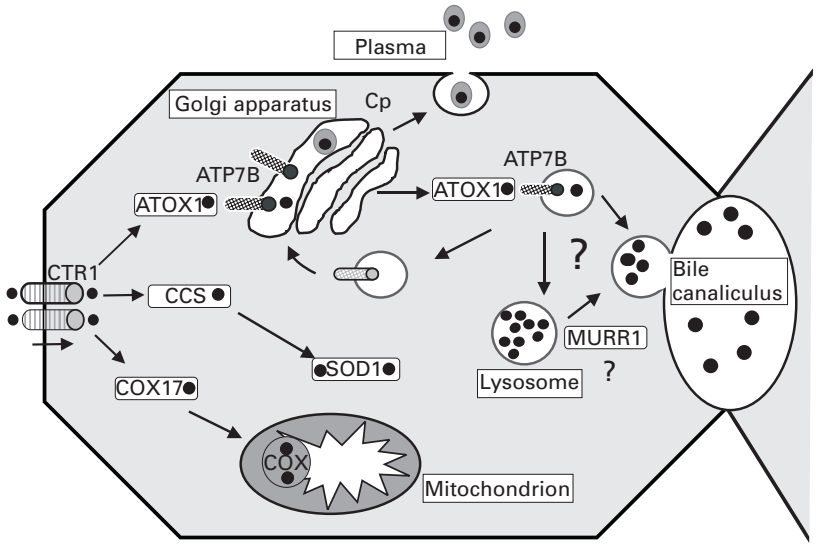

Fig. 2. Current view of hepatocyte copper (0) metabolism. After entering the cell via the copper transporter 1 (CTR1), copper is delivered to three different pathways by the copper chaperones ATOX1, copper chaperone for superoxide dismutase (SOD) 1 (CCS) and cytochrome C oxidase (COX) assembly factor 17 (COX17) respectively. Copper-transporting P-type ATPase (ATP7B) is essential for copper delivery to caeruloplasmin (Cp), which is excreted in the plasma. When copper concentration is raised, the ATP7B protein redistributes to a pericanalicular vesicular compartment. The biliary excretion of copper is still not well understood, but research suggests a major role for MURR1 (a protein of unknown function) in biliary excretion via a vesicular compartment. The copper import and delivery pathways are strongly conserved from yeast to man; the lysosomal excretion pathway is probably restricted to vertebrates.

knowledge of this cellular process (Askwith \& Kaplan, 1998; De Freitas et al. 2003).

\section{Copper excretion from hepatocytes}

To allow efficient elimination of toxic compounds via biliary excretion, hepatocytes have developed mechanisms that generally apply to many different substances. Hepatocytes are polarized into an apical (canalicular) domain and a basolateral (sinusoidal) domain. The canalicular membrane is equipped with many different transport proteins responsible for the cellular elimination of physiological and toxic compounds. Most of these transporters belong to the $\mathrm{ABC}$ transporter superfamily (Oude Elferink \& Groen, 2002) and the expression of these proteins at the canalicular membrane is partly regulated at the transcriptional level (Trauner \& Boyer, 2003). It has recently become clear that some of these $\mathrm{ABC}$ transporters reside in intracellular compartments and are delivered to the canalicular domain following increased physiological demand (Kipp \& Arias, 2002). A putative role for the lysosomal compartment in biliary secretion has long been suspected, but currently remains unclear (Gross et al. 1989; Nakano et al. 1995).

$\mathrm{Cu}$ excretion from the hepatocyte is achieved in part by mechanisms that meet these general principles, but there are also some important notable differences. The current working model of the cellular machinery mediating $\mathrm{Cu}$ acquisition, redistribution and excretion in the hepatocyte is presented in Fig. 2 and described in more detail later (see p. 33). 


\section{Copper-transporting P-type ATPase ATP7B is a hepatocyte copper transporter}

The transmembrane transport of $\mathrm{Cu}$ is mediated not by an ABC transporter but by ATP7B, a member of a highlyconserved family of heavy-metal-transporting P-type ATPases (Bull et al. 1993; Petrukhin et al. 1993; Tanzi et al. 1993; Yamaguchi et al. 1993). ATP7B is expressed predominantly in the liver and is structurally and functionally homologous with $A T P 7 A$, the gene mutated in the $\mathrm{Cu}$-deficiency disorder Menkes disease (Fig. 1; Vulpe et al. 1993; Payne \& Gitlin, 1998). ATP7B is mutated in Wilson disease, and the hepatic accumulation of $\mathrm{Cu}$ observed in patients with this autosomal recessive disorder suggests that ATP7B plays a central role in biliary $\mathrm{Cu}$ excretion, and that the biochemical function of ATP7B is in the transport of $\mathrm{Cu}$ across cellular membranes (Fig. 1). The ATP7B protein contains six tandemly-repeated heavymetal-binding regions in its N-terminal domain. ATP7B is required for $\mathrm{Cu}$ insertion from the cytosol into the trans Golgi network, and most mutations associated with Wilson disease abolish this biochemical activity (Payne \& Gitlin, 1998). Consistent with these observations, but in contrast to most other transporters in the liver cell, ATP7B is localized in the trans Golgi network under normal physiological conditions (Hung et al. 1997; Huster et al. 2003). Here the $\mathrm{Cu}$ is incorporated into apocaeruloplasmin, to form the redox-active holoenzyme caeruloplasmin.

In accordance with the observed induced intracellular relocalization of hepatocyte transport proteins, ATP7B is also localized in different cellular compartments depending on the $\mathrm{Cu}$ status of the cell. When cellular $\mathrm{Cu}$ levels are raised this P-type ATPase is rapidly translocated from the trans Golgi network to a vesicular compartment diffusely localized within the cell (Hung et al. 1997). This $\mathrm{Cu}$-dependent relocalization is fast and does not require de novo protein synthesis. In addition, this phenomenon is reversible, since subsequent depletion of $\mathrm{Cu}$ results in the rapid return of ATP7B to the trans Golgi network. In polarized HepG2 hepatoma cells ATP7B redistributes to vesicular structures and to apical vacuoles reminiscent of bile canaliculi under high- $\mathrm{Cu}$ conditions (Roelofsen et al. 2000). Taken together, these data suggest that ATP7B is continuously cycling through different cellular compartments and that $\mathrm{Cu}$ availability regulates the efficiency and velocity of specific retrieval steps. The molecular mechanisms of $\mathrm{Cu}$-dependent cycling of ATP7B are largely unknown, but some recent studies have suggested that $\mathrm{Cu}-$ dependent signal transduction pathways may be involved (Vanderwerf et al. 2001). It is possible that the unidentified ATP7B-containing vesicles represent some form of endosomal compartment, since excess $\mathrm{Cu}$ can be sequestered in lysosomes (Myers et al. 1993). Cu overload causes alterations in lysosomal morphology and increases lysosomal pH (Myers et al. 1993). Hepatocytes respond to a greater $\mathrm{Cu}$ load by sequestering excess $\mathrm{Cu}$ in more lysosomes that can empty their contents directly into the bile (Gross et al. 1989). These results provide evidence that exocytosis of lysosomal contents into biliary canaliculi is an important mechanism for biliary $\mathrm{Cu}$ excretion, at least during hepatic $\mathrm{Cu}$ overload (Gross et al. 1989; Myers et al. 1993).

\section{The role of ATOX1 in hepatic copper excretion}

An important protein in the $\mathrm{Cu}$ excretion pathway mediated by ATP7B is the small cytosolic $\mathrm{Cu}$ chaperone ATOX1. ATOX1 is a protein of sixty-eight amino acid residues with a similar structural fold to each of the six metal-binding sites in ATP7B (Klomp et al. 1997; Wernimont et al. 2000). ATOX1 itself can bind $\mathrm{Cu}$ and it undergoes a transient $\mathrm{Cu}$-dependent association with ATP7B (Hamza et al. 1999; Larin et al. 1999). This $\mathrm{Cu}-$ dependent association between ATP7B and ATOX1 seems essential for efficient $\mathrm{Cu}$ transport, since mutations in ATP7B that abolish this interaction are associated with Wilson disease (Hamza et al. 1999). Consistent with this finding, mice with a deletion of the murine Atoxl locus have severe abnormalities in cellular $\mathrm{Cu}$ metabolism (Hamza et al. 2001). Based on work in yeast, it has been postulated that ATOX1 binds and detoxifies cytosolic $\mathrm{Cu}$ and presents the metal to ATP7B for subsequent transmembrane transport (Pufahl et al. 1997). A second hypothesis for the biological function of ATOX1 in the cell has been put forward by Lutsenko and coworkers (Walker et al. 2002), who showed that ATOX1 stimulates the catalytic activity of ATP7B. Most recently, elegant experiments by Hamza et al. (2003) have revealed that $\mathrm{Cu}$-dependent subcellular trafficking of ATP7A is markedly impaired in cells isolated from Atox $1^{-/-}$mice. They proposed that ATOX1 is essential for the regulation of $\mathrm{Cu}$-dependent trafficking of ATP7A, and presumably also that of ATP7B. Future research should be aimed at the exciting possibility of unifying these three hypotheses into a single coherent working model for the molecular role of ATOX1 in the regulation of ATP7B-mediated cellular $\mathrm{Cu}$ excretion.

\section{MURR1, a new copper-metabolism gene?}

Solving the aetiology of disorders of $\mathrm{Cu}$ homeostasis other than Menkes disease and Wilson disease, both in man and animals, may further increase our knowledge of the regulation of $\mathrm{Cu}$ homeostasis. Some years ago the authors became interested in a form of $\mathrm{Cu}$ toxicosis in dogs that has long been considered an excellent model for studying hepatic $\mathrm{Cu}$ overload and developing therapeutic approaches in man. Canine $\mathrm{Cu}$ toxicosis (CT) is an autosomal recessive disorder with a high frequency in Bedlington terriers (Hardy et al. 1975). Dietary intake of $\mathrm{Cu}$ in these animals is normal, but biliary $\mathrm{Cu}$ excretion is markedly reduced compared with control animals (Fig. 1; Su et al. 1982). Animals that are affected have $\mathrm{Cu}$ concentrations of $>1000 \mu \mathrm{g} / \mathrm{g}$ liver dry weight. The excess $\mathrm{Cu}$ is stored in the lysosomes of hepatocytes, resulting in liver cirrhosis, and unless treated the dogs die at between 2 and 6 years of age. The $\mathrm{Cu}$-chelation therapy used in Wilson disease is effective in Bedlington terriers. The disorder has a clear idiopathic component, since reduced penetrance of CT has been described in association with low dietary $\mathrm{Cu}$ intake. There are distinct differences between the characteristics 
of CT and those of the classic Wilson disease: the absence of neurological manifestations; the normal caeruloplasmin concentrations in plasma. $\mathrm{Cu}$ toxicosis resembles Indian childhood cirrhosis (Tanner et al. 1979) and endemic Tyrolean infantile cirrhosis (Müller et al. 1996), two fatal human hepatic $\mathrm{Cu}$ overload disorders of unknown aetiology (Fig. 1). A breakthrough in the molecular characterization of CT was the localization of the gene defect to canine chromosome 10, region q26 (van de Sluis et al. 1999). Based on the map location of the CT locus, mutations in the canine $A T P 7 B$ and $A T O X 1$ genes could be excluded as the cause of the disorder because these genes mapped to canine chromosomes $22 \mathrm{q} 11$ and $4 \mathrm{q} 24-\mathrm{q} 31$ respectively (Dagenais et al. 1999; Nanji \& Cox, 1999; van de Sluis et al. 2001).

The availability of large Bedlington terrier pedigrees segregating $\mathrm{CT}$ has made it possible to embark on a positional cloning strategy to identify the gene mutated in CT (an outline of positional cloning is depicted in Fig. 3; van de Sluis et al. 1999, 2000).

More recently, it was shown that this disorder is associated with a deletion of exon 2 of the MURRI gene, at the cDNA level (van de Sluis et al. 2002). At the genomic level the mutation in Bedlington terriers spans at least $13 \mathrm{~kb}$ and encompasses exon 2 of the MURRI gene. Hence, this rearrangement is predicted to cause an in-frame deletion of the MURR1 transcript, presumably leading to the formation of a shortened MURR1 protein product of ninety-four amino acid residues instead of the predicted 188 residues (Fig. 3). It was predicted that this short protein product would be unstable and therefore lead to a complete loss of MURR1 function. Consistent with this hypothesis, it has been established experimentally that the deletion is indeed associated with a complete absence of detectable MURR1 protein from the livers of affected Bedlington terriers, whereas the protein is expressed as a $23 \mathrm{kDa}$ single-chain polypeptide in the livers of unaffected dogs (Klomp et al. 2003b). Importantly, mutations in MURR1 are not associated with Indian childhood cirrhosis and endemic Tyrolean infantile cirrhosis in man (Müller et al. 2003). Taken together, these data strongly suggest that MURR1 plays a rate-limiting role in $\mathrm{Cu}$ excretion from hepatocytes during $\mathrm{Cu}$ overload, at least in the dog. Experiments using Murrl knock-out mice and knock-down of MURR1 by RNA interference are underway to extend these observations to other species. Another exciting possibility includes the structural characterization of MURR1. Much of the current knowledge of the biochemistry of intracellular $\mathrm{Cu}$ homeostasis has come from $\mathrm{x}$-ray crystallography and NMR-based structural analysis of proteins involved in $\mathrm{Cu}$ metabolism. It has now become essential to determine the crystal structure of MURR1.

Clearly, MURRI deficiency provides a unique opportunity to study the cellular biology of hepatic $\mathrm{Cu}$ excretion. MURRI encodes a protein that is currently of unknown function and has no detectable sequence homology to known proteins. MURRI mRNA is expressed abundantly in liver tissue, but is also readily detected in other tissues. Using a specific polyclonal antibody raised against MURR1, ubiquitous Murr1 protein expression was recently identified in murine organs and human cell lines. From these data it has been postulated that MURR1 could perform a pleiotropic function in different organs, not exclusively linked to $\mathrm{Cu}$ homeostasis. Several lines of indirect evidence suggest that MURR1 may function in the ATOX1ATP7B-mediated pathway of $\mathrm{Cu}$ excretion, probably downstream of ATP7B. MURR1-deficient Bedlington terriers have normal plasma holocaeruloplasmin activity, but a markedly elevated lysosomal $\mathrm{Cu}$ content and a strongly reduced biliary $\mathrm{Cu}$ excretion. This finding suggests that $\mathrm{Cu}$ transport by ATP7B into the Golgi apparatus is normal, and indicates that MURR1 deficiency does not lead to a complete inhibition of the Cu-transporting activity of ATP7B. Rather, MURR1 deficiency may lead to an inefficient degranulation of lysosomal contents into bile during $\mathrm{Cu}$ overload (Fig. 2). Consistent with the lysosomal $\mathrm{Cu}$ accumulation in affected Bedlington terriers, it was observed that exogenous and endogenous MURR1 is partially localized to a vesicular compartment, reminiscent of the endosomal-lysosomal system, in several cell lines (Klomp et al. 2003b). These preliminary findings will have to be further corroborated both in cultured cells and in liver tissue.

\section{Is there a link between copper import and export?}

$\mathrm{Cu}$ import in yeast is mediated by the homologous $\mathrm{Cu}$ transporters Ctr1-3 (Puig et al. 2002). The human orthologous genes, $h C T R 1$ and $h C T R 2$, show limited sequence homology with the yeast Ctrl gene (Zhou \& Gitschier, 1997). The hCTRl gene encodes a protein of 190 amino acids, which is glycosylated, forms oligomers and is ubiquitously expressed (Klomp et al. 2002, 2003a; Eisses \& Kaplan, 2002). CTR1 proteins span the membrane multiple times, permitting formation of a channel, which is consistent with its proposed role as a high-affinity $\mathrm{Cu}$ permease (Puig et al. 2002; Eisses \& Kaplan, 2002; Klomp et al. 2003a). The subcellular localization of CTR1 differs markedly between different cell types, ranging from a predominant intracellular vesicular perinuclear compartment to a location on the plasma membrane. The subpool of CTR1 present on the plasma membrane undergoes rapid internalization and degradation when the extracellular $\mathrm{Cu}$ concentration is elevated (Petris et al. 2003). It is tempting to speculate that the $\mathrm{Cu}$-dependent internalization of CTR 1 is regulated by mechanisms similar to those for the metal-dependent redistribution of ATP7A and ATP7B, thereby providing a mechanistic link between the regulation of $\mathrm{Cu}$ import and export. Homozygous null mice at the Ctrl locus exhibit profound delays in growth and development and die at embryonic day $7 \cdot 5$, presumably as a consequence of $\mathrm{Cu}$ deficiency (Kuo et al. 2001; Lee et al. 2001). These studies demonstrated a crucial ratelimiting role for CTR1 in $\mathrm{Cu}$ acquisition and embryonic development in mammals and support the hypothesis that cellular $\mathrm{Cu}$ homeostasis is regulated at the level of both $\mathrm{Cu}$ import and $\mathrm{Cu}$ excretion. It would be interesting to determine the exact role of CTR 1 in dietary $\mathrm{Cu}$ uptake and investigate whether putative mild variations in CTR1 structure and/or regulation of plasma membrane expression are associated with differences in acquisition of $\mathrm{Cu}$ in the population. 


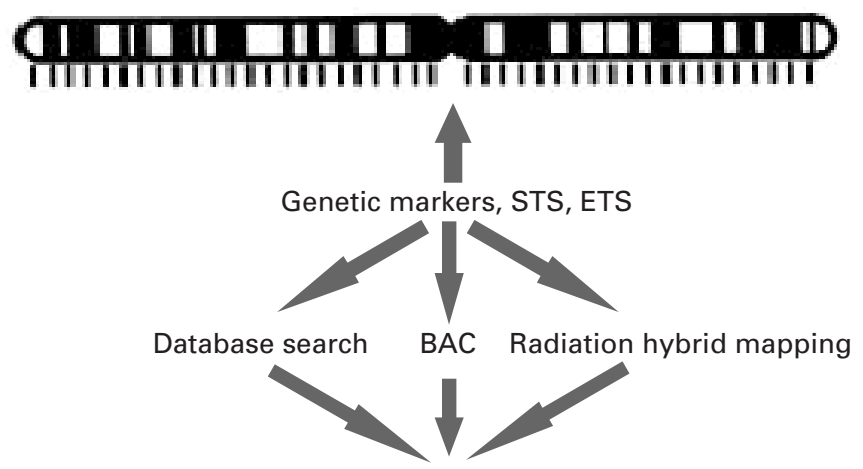

Physical map, transcript map

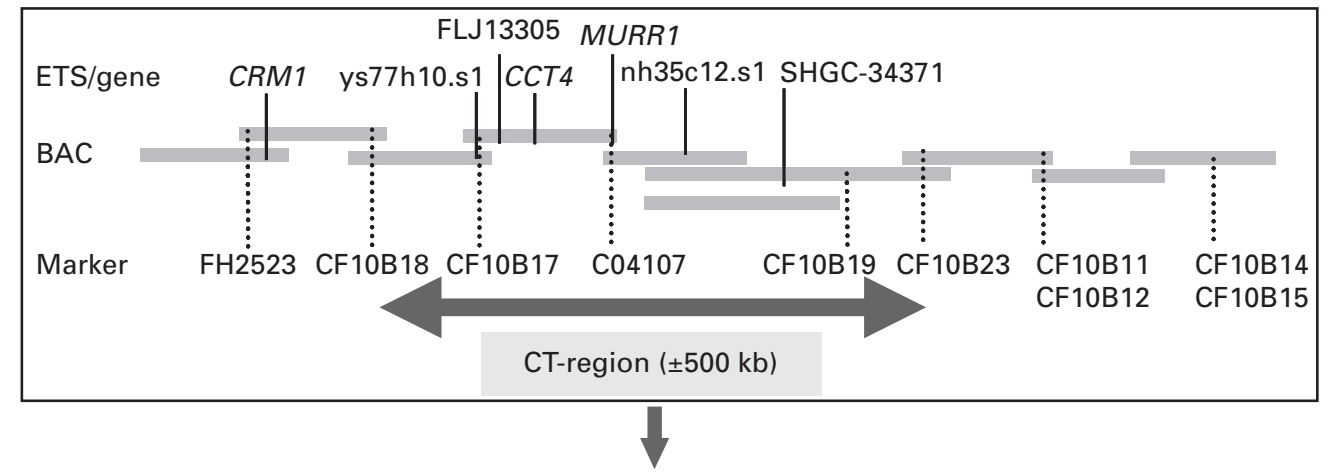

Sequence analysis MURR1 in affected CT dogs
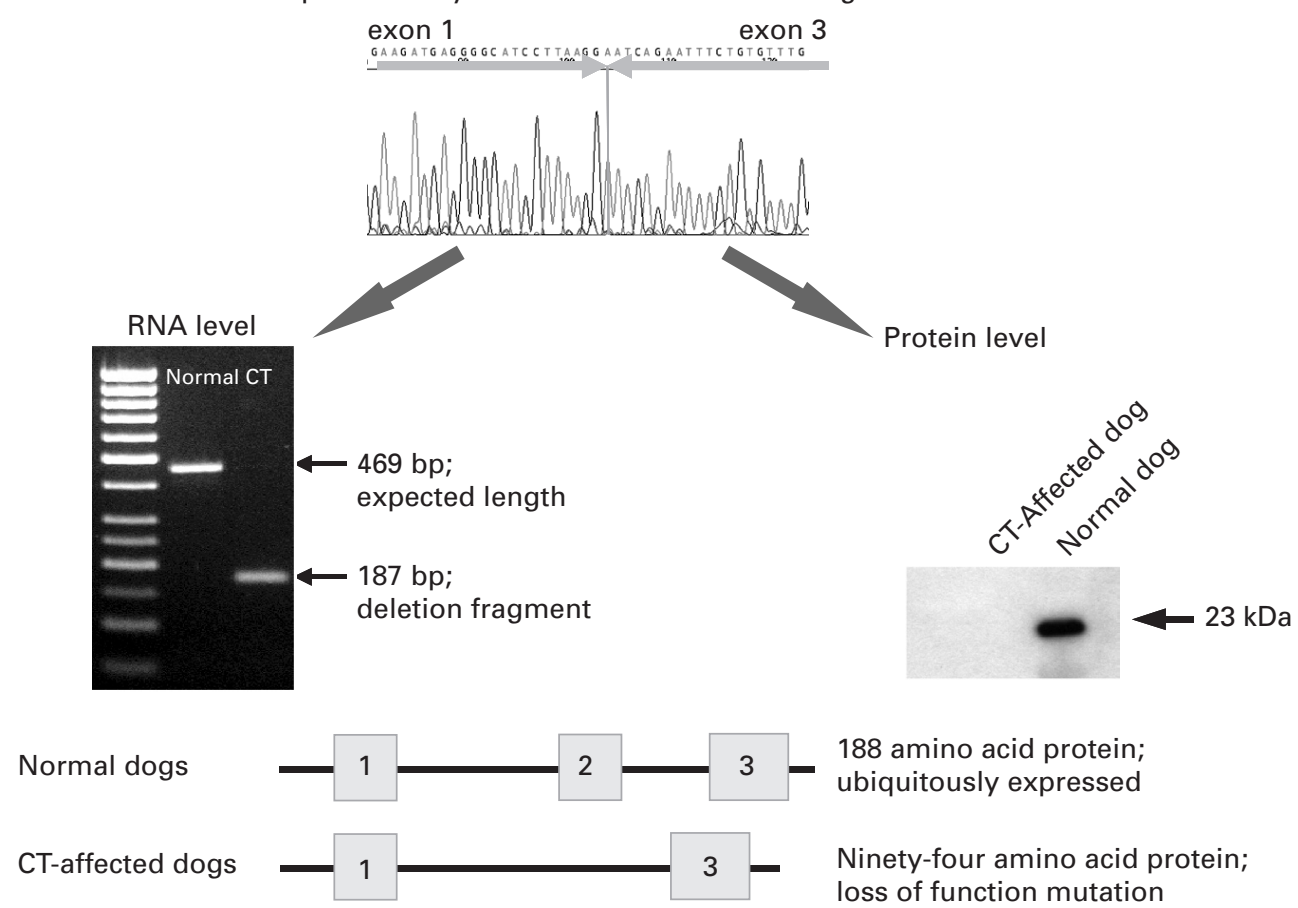

Fig. 3. Schematic overview of positional cloning strategy employed in cloning the MURR1 gene. Genetic mapping was used to map the disease gene onto the dog genome (Yuzbasiyan-Gurkan et al. 1997). The map location was determined by comparative mapping (van de Sluis et al. 1999). Radiation hybrid mapping was used to construct a physical map (van de Sluis et al. 2000). A bacterial artificial chromosome (BAC) contig was constructed and new polymorphic markers were isolated from the BAC clones to narrow down the canine copper toxicosis (CT) gene region further by genetic mapping. Haplotype sharing revealed a region of approximately $500 \mathrm{~kb}$ to be shared by all affected animals. This region contained seventeen putative transcripts, four of which were subjected to mutation analysis by sequencing. The MURR1 gene was mutated in affected Bedlington terriers, which was associated with a short RNA product (van de Sluis et al. 2002). The mutation results in a loss of function, since no protein can be detected in the livers of affected dogs (Klomp et al. 2003). STS, sequence tagged site; ETS, expression tagged site. 


\section{Functional characterization of MURR1}

The current challenge is to enhance the understanding of MURR1 function in relation to hepatic $\mathrm{Cu}$ homeostasis. In addition to the cell biology approach to the dissection of MURR1 function described earlier, the availability of whole genome sequences and high-throughput genomic and proteomic technologies will offer new opportunities to address MURR1 function and to identify the cellular and molecular pathways in which MURR1 acts. Such a multidisciplinary approach will not only allow us to investigate phenotype-related processes, but will also provide tools to unravel the molecular aspects of the normal adaptive response of cells, tissues and organisms to dietary $\mathrm{Cu}$ (Fig. 4).

\section{Comparative genomics}

The complete genome sequences of more than eighty-five bacteria, five different yeast strains and eight eukaryotes have been determined. By the end of 2003 whole genome sequences of many additional eukaryotes will be available. Genome analysis and sequence comparisons will contribute to our understanding of gene structure, gene function and gene evolution.

Comparing the gene sequence of MURRl with the fullysequenced genomes available to date showed that orthologues of MURRI are present in a number of vertebrates, including man, but they could not be detected in lower eukaryotes and prokaryotes (van de Sluis et al. 2002). This finding is in contrast to the results for other proteins of $\mathrm{Cu}$ metabolism, which are clearly well conserved in lower eukaryotes. The presence of the MURR1 proteins may be related to the presence of bile and its participation in the excretion of toxic compounds, which is a unique feature of vertebrate organisms. Much of our current insight into the homeostatic control of $\mathrm{Cu}$ metabolism is in fact based on studies of $\mathrm{Cu}$ homeostasis in yeast (Askwith \& Kaplan, 1998; De Freitas et al. 2003).

Comparative genomics can also be a powerful tool for determining which parts of a gene harbour important functions, as these parts are usually subject to strong selection and are, therefore, expected to show the highest level of sequence conservation. Furthermore, a comparison of the non-coding regions surrounding a gene may also identify highly-conserved regions, which generally indicate important regulatory elements such as promoters and enhancers (Muller et al. 2002).

\section{Gene expression profiling}

Microarrays are being used to measure the levels of expression of thousands of genes simultaneously. Commercial microarrays ('chips') with a large number of genes are currently available for different species. There are a number of different technologies and platforms on the market, but the general principles underlying each of them are similar. In brief, equal amounts of two fluorescentlylabelled RNA preparations are simultaneously hybridized onto a chip. Transcripts with differential expression between the two samples will show only a signal from one fluorescent dye (Duggan et al. 1999).

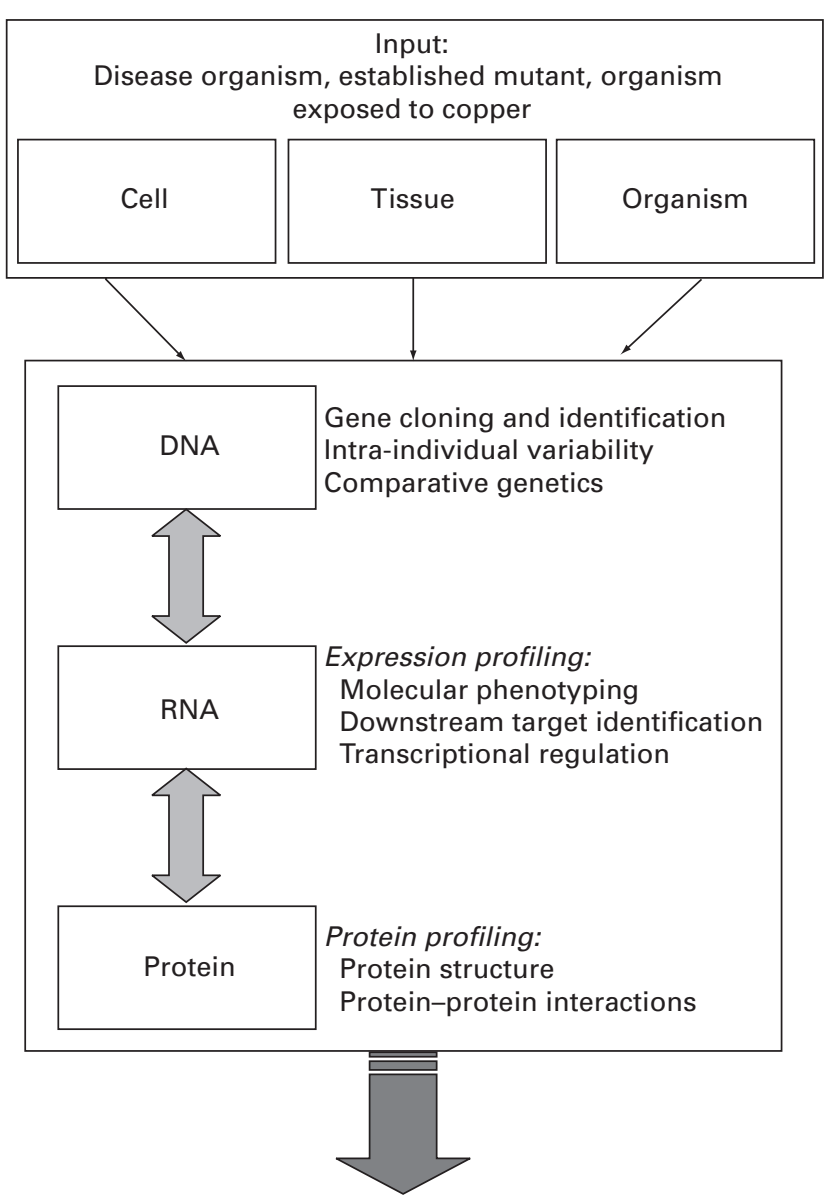

Understanding gene function in complex biological networks: Elucidating copper signalling pathways

Defining molecular biomarkers of copper response Identifying allelic variants associated with, or modulating phenotype

Fig. 4. Overview of the multidisciplinary approach taken to understand MURR1 gene function and to identify the molecular pathways in which MURR1 is involved. A gene-driven approach using genomic information for identifying genes (DNA and RNA) and gene products (protein) involved in certain cellular processes can be performed. This approach will also be extremely useful in nutrigenomics research, when studying the adaptive response to copper in relation to genetic background. Alternatively, a phenotype-driven approach analyses phenotypes from human pathologies or animal mutants. This approach will initially unravel the primary genes involved in the disease process and subsequently the molecular pathway(s) in which such a gene operates.

This technology is potentially an extremely powerful tool for assigning gene function and deciphering regulatory networks. To identify the possible cellular and molecular mechanisms in which MURR1 plays an essential role, cells with a mutant $M U R R I$ can be profiled under different $\mathrm{Cu}$ conditions. Mutant MURRI cells may be obtained from in vivo models (e.g. affected dogs or knock-out mice), or from in vitro models (e.g. knock-out or knock-down cells). The current disadvantage of the natural MURRl mutant, the Bedlington terrier, is the lack of canine-specific microarrays.

Microarray studies can also be a powerful tool for providing information on the normal adaptive cellular 
response to $\mathrm{Cu}$ exposure and the regulatory mechanism involved. A recent study in yeast grown under changing $\mathrm{Cu}$ conditions (Gross et al. 2000) indicated the presence of a limited set of yeast genes that are differentially expressed under $\mathrm{Cu}$-excess or $\mathrm{Cu}$-replete conditions. A preliminary time-course experiment $(\mathrm{H}$ van Bakel and $\mathrm{C}$ Wijmenga, unpublished results), in which both the acute and longterm responses in either $\mathrm{Cu}$-excess or $\mathrm{Cu}$-starvation conditions were measured in yeast, revealed seven new genes that had not previously been implicated in $\mathrm{Cu}$ metabolism. Although most genes involved in $\mathrm{Cu}$ transport in yeast have human homologues, the situation is not the same for the $\mathrm{Cu}$-induced transcription factors Ace1 and Mac1. It has been suggested that in vertebrates $\mathrm{Cu}$ itself is not involved in regulating the expression of genes (Linder, 2001). However, a pilot experiment in human cultured fibroblasts showed that increasing $\mathrm{Cu}$ levels promotes a rapidlyinduced expression of a number of genes, including metallothioneins (P Muller and $\mathrm{C}$ Wijmenga, unpublished results). These results have two major implications. First, they suggest that $\mathrm{Cu}$-dependent regulation of transcription does indeed exist in mammalian cells. Second, they indicate that in addition to the regulation of $\mathrm{Cu}$ import and $\mathrm{Cu}$ export from the cells $\mathrm{Cu}$ may also directly regulate intracellular sequestration of the metal. It is not yet clear whether $\mathrm{Cu}$ is associated with transcription factors that bind to promoters of $\mathrm{Cu}$-regulated genes. The identification of $\mathrm{Cu}$-responsive genes will allow their promoter regions to be analysed and will promote the search for common elements that may be responsible for $\mathrm{Cu}$-mediated regulation of expression.

More recently, it has also become evident that microarray technology may become an important tool in toxicology (Hamadeh et al. 2002; Waring \& Halbert, 2002; Vrana et al. 2003). In the future it should be possible to compare the patterns of gene expression associated with novel chemicals with databases that contain patterns of expression for known chemicals and toxic compounds, including transition metals. Moreover, microarray studies could also be instrumental in determining the toxic dose of $\mathrm{Cu}$ from dose-response relationships. For the latter it is evident that there should be some knowledge of the normal adaptive response to $\mathrm{Cu}$ in individual organs or cell types.

\section{Proteomics}

Recently, it was shown that the $\mathrm{Cu}$ chaperones exhibit a specific transient protein-protein interaction with their respective target proteins. These interactions are $\mathrm{Cu}$ dependent and necessary for efficient $\mathrm{Cu}$ transfer from the chaperone to the target proteins (Pufahl et al. 1997). These data support the existence of a protein-protein interaction network in which $\mathrm{Cu}$ is transferred from one protein to another depending on the requirement to synthesize cuproenzymes in different organelles, or alternatively to store or excrete the metal. The presence of this network provides an opportunity to identify novel proteins that play a role in $\mathrm{Cu}$ homeostasis simply by isolating 'new' proteins that interact with known proteins. During the last decade, novel high-throughput methods have been developed and successfully applied to the identification of protein-protein interaction networks. A comprehensive analysis of protein-protein interactions was carried out recently in the yeast $S$. cerevisiae (Ito et al. 2000; Uetz et al. 2000). The yeast-two hybrid method has been applied to the identification of MURR1 interacting proteins. In preliminary experiments a previously unknown protein that specifically interacts with MURR1 was isolated and tentatively named MURR1-interacting protein 1 (P de Bie, LW Klomp and $\mathrm{C}$ Wijmenga, unpublished results). The interaction of MURR1 with MURR1-interacting protein 1 has been confirmed by independent techniques. Although the function of MURR1-interacting protein 1 and the relevance of its interaction with MURR1 need to be further established, these preliminary data illustrate the relevance of this approach in characterizing functional pathways in $\mathrm{Cu}$ homeostasis, which may also lead to the identification of novel candidate genes for human $\mathrm{Cu}$-overload disorders, including Indian childhood cirrhosis and endemic Tyrolean infantile cirrhosis.

\section{Model systems}

Yeast has been used widely as a model organism in the study of $\mathrm{Cu}$ metabolism (Askwith \& Kaplan, 1998; De Freitas et al. 2003). Although the yeast system shows strong homology in $\mathrm{Cu}$ uptake and cellular distribution to the systems in higher vertebrates, including man, the excretion process is rather different. A mouse model with a MURR 1 mutation similar to that seen in Bedlington terriers is currently being constructed by homologous recombination in mouse embryonic stem cells. These mice will serve different purposes. They will confirm the disease-causing phenotype, they will help in defining the MURRl gene function and, finally, they may become useful for the study of gene-diet interactions. These mice will be subjected to the techniques described earlier; microarray analysis, for example, is expected to reveal multiple genes that act downstream of MURR1. It could become rather time-consuming and expensive to produce knock-out or transgenic mice for a number of these downstream targets in order to functionally characterize them. The availability of RNA interference has introduced a powerful tool for studying gene function in mammals by inducing post-transcriptional gene silencing, both in vitro and in vivo (Brummelkamp et al. 2002).

\section{Future perspectives}

It is becoming evident that most traits and disorders have a genetic basis. It is therefore tempting to speculate that an individual's susceptibility to dietary $\mathrm{Cu}$ may also have a genetic background. Individual variation in genes involved in either the uptake or excretion of $\mathrm{Cu}$ might render an individual or animal more susceptible or resistant to $\mathrm{Cu}$. The cases of Indian childhood cirrhosis in India and endemic Tyrolean infantile cirrhosis are clear examples. However, both the lack of appropriate molecular markers for the assessment of Cu-related genotypes, and the lack of biomarkers for the assessment of intracellular $\mathrm{Cu}$ levels have hampered studies carefully designed to address this problem. The new research field of nutrigenomics is the 
application of high-throughput genomic tools to nutrition research (Müller \& Kersten, 2003). This approach will increase our understanding of how nutrition influences metabolic pathways and homeostatic control, and how this regulation is disturbed under changing dietary conditions or diet-induced diseases in relation to the individual's background.

Currently, $A T P 7 B$ is the only $\mathrm{Cu}$ toxicosis-related gene known to be present in man. Given that the frequency of Wilson disease is one in 30000 , approximately one in every eighty-seven individuals must carry at least one $A T P 7 B$ mutation. It would be interesting to investigate whether there is a potential risk associated with being an $A T P 7 B$ mutation carrier when exposed to conditions of high levels of exogenous $\mathrm{Cu}$, e.g. through drinking water contaminated by domestic $\mathrm{Cu}$ piping. Large populationbased studies will be required to establish 'Cu-related cellular phenotypes' by the application of a range of genomic, proteomic and metabolomic tools (Bochner, 2003; Freimer \& Sabatti, 2003).

It is expected that the work on MURR1 and its pathway will reveal a group of genes that are directly or indirectly involved in modulating hepatocellular $\mathrm{Cu}$ levels. New technological advances will make it possible to compile extensive genetic profiles using single nucleotide polymorphisms that capture the genetic variation of these genes.

\section{Acknowledgements}

The authors thank Harm van Bakel, Prim de Bie \& Patricia Muller for permitting unpublished work to be cited, Bernard van Oost, Diana Klomp and Matthew Hestand for helpful discussions and Jackie Senior for critical reading of the manuscript. The work of the authors is supported by The Netherlands Organization for Scientific Research (Zon-MW), the Dutch Digestive Disease Foundation (MLDS), the Wilhelmina Children's Hospital (WKZ) Fund and the International Copper Association (ICA).

\section{References}

Askwith C \& Kaplan J (1998) Iron and copper transport in yeast and its relevance to human disease. Trends in Biochemical Sciences 23, 135-138.

Bochner BR (2003) New technologies to assess genotypephenotype relationships. Nature Reviews Genetics 4, 309-314.

Brummelkamp TR, Bernards R \& Agami R (2002) A system for stable expression of short interfering RNAs in mammalian cells. Science 296, 550-553.

Bull PC, Thomas GR, Rommens JM, Forbes JR \& Cox DW (1993) The Wilson disease gene is a putative copper transporting P-type ATPase similar to the Menkes gene. Nature Genetics 5, 327-337.

Dagenais SL, Guevara-Fujita M, Loechel R, Burgess AC, Miller DE, Yuzbasiyan-Gurkan V, Brewer GJ \& Glover TW (1999) The canine copper toxicosis locus is not syntenic with ATP7B or ATX1 and maps to a region showing homology to human 2p21. Mammalian Genome 10, 753-756.

De Freitas J, Wintz H, Kim JH, Poynton H, Fox T \& Vulpe C (2003) Yeast, a model organism for iron and copper metabolism studies. Biometals 16, 185-197.
Duggan DJ, Bittner M, Chen Y, Meltzer P \& Trent JM (1999) Expression profiling using cDNA microarrays. Nature Genetics 21, Suppl., 10-14.

Eisses JF \& Kaplan JH (2002) Molecular characterization of hCTR1, the human copper uptake protein. Journal of Biological Chemistry 277, 29162-29171.

Freimer N \& Sabatti C (2003) The human phenome project. Nature Genetics 34, 15-21.

Gross C, Kelleher M, Iyer VR, Brown PO \& Winge DR (2000) Identification of the copper regulon in Saccharomyces cerevisiae by DNA microarrays. Journal of Biological Chemistry 275, 32310-32316.

Gross JB Jr, Myers BM, Kost LJ, Kuntz SM \& LaRusso NF (1989) Biliary copper excretion by hepatocyte lysosomes in the rat: Major excretory pathway in experimental copper overload. Journal of Clinical Investigations 83, 30-39.

Hamadeh HK, Amin RP, Paules RS \& Afshari CA (2002) An overview of toxicogenomics. Current Issues in Molecular Biology 4, 45-56.

Hamza I, Faisst A, Prohaska J, Chen J, Gruss P \& Gitlin JD (2001) The metallochaperone Atox 1 plays a critical role in perinatal copper homeostasis. Proceedings of the National Academy of Sciences USA 98, 6848-6852.

Hamza I, Prohaska J \& Gitlin JD (2003) Essential role for Atox1 in the copper-mediated intracellular trafficking of the Menkes ATPase. Proceedings of the National Academy of Sciences USA 100, 1215-1220.

Hamza I, Schaefer M, Klomp LW \& Gitlin JD (1999) Interaction of the copper chaperone HAH1 with the Wilson disease protein is essential for copper homeostasis. Proceedings of the National Academy of Sciences USA 96, 13363-13368.

Hardy RM, Stevens JB \& Stowe CM (1975) Chronic progressive hepatitis in Bedlington terriers associated with elevated liver copper concentrations. Minnesota Veterinarian 15, 13-24.

Hung IH, Suzuki M, Yamaguchi Y, Yuan DS, Klausner RD \& Gitlin JD (1997) Biochemical characterization of the Wilson disease protein and functional expression in the yeast Saccharomyces cerevisiae. Journal of Biological Chemistry 272, 21461-21466.

Huster D, Hoppert M, Lutsenko S, Zinke J, Lehmann C, Mossner J, Berr F \& Caca K (2003) Defective cellular localization of mutant ATP7B in Wilson's disease patients and hepatoma cell lines. Gastroenterology 124, 335-345.

Ito $\mathrm{T}$, Tashiro $\mathrm{K}$, Muta S, Ozawa R, Chiba T, Nishizawa M, Yamamoto K, Kuhara S \& Sakaki Y (2000) Toward a protein-protein interaction map of the budding yeast: A comprehensive system to examine two-hybrid interactions in all possible combinations between the yeast proteins. Proceedings of the National Academy of Sciences USA 97, 1143-1147.

Kipp H \& Arias IM (2002) Trafficking of canalicular ABC transporters in hepatocytes. Annual Review of Physiology 64, 595-608.

Klomp AE, Juijn JA, van der Gun LT, van den Berg IE, Berger R \& Klomp LW (2003a) The N-terminus of the human copper transporter 1 (hCTR1) is localized extracellularly, and interacts with itself. Biochemical Journal 370, 881-889.

Klomp AE, Tops BB, Van Denberg IE, Berger R \& Klomp LW (2002) Biochemical characterization and subcellular localization of human copper transporter 1 (hCTR1). Biochemical Journal 364, 497-505.

Klomp AEM, van de Sluis B, Klomp LWJ \& Wijmenga C (2003b) The ubiquitously expressed MURR1 protein is absent in canine copper toxicosis. Journal of Hepatology 39, 703-709.

Klomp LW, Lin SJ, Yuan DS, Klausner RD, Culotta VC \& Gitlin JD (1997) Identification and functional expression of HAH1, a novel human gene involved in copper homeostasis. Journal of Biological Chemistry 272, 9221-9226. 
Kuo YM, Zhou B, Cosco D \& Gitschier J (2001) The copper transporter CTR1 provides an essential function in mammalian embryonic development. Proceedings of the National Academy of Sciences USA 98, 6836-6841.

Larin D, Mekios C, Das K, Ross B, Yang AS \& Gilliam TC (1999) Characterization of the interaction between the Wilson and Menkes disease proteins and the cytoplasmic copper chaperone, HAH1p. Journal of Biological Chemistry 274, 28497-28504.

Lee J, Prohaska JR \& Thiele DJ (2001) Essential role for mammalian copper transporter Ctr1 in copper homeostasis and embryonic development. Proceedings of the National Academy of Sciences USA 98, 6842-6847.

Linder MC (2001) Copper and genomic stability in mammals. Mutation Research 475, 141-152.

Muller F, Blader P \& Strahle U (2002) Search for enhancers: teleost models in comparative genomic and transgenic analysis of cis regulatory elements. Bioessays 24, 564-572.

Müller M \& Kersten S (2003) Nutrigenomics: goals and strategies. Nature Reviews Genetics 4, 315-322.

Müller T, Feichtinger H, Berger H \& Müller W (1996) Endemic Tyrolean infantile cirrhosis: an ecogenetic disorder. Lancet 347, 877-880.

Müller T, van de Sluis B, Zhernakova A, van Binsbergen E, Janecke AR, Bavdekar A et al. (2003) The canine copper toxicosis gene MURR1 does not cause non-Wilsonian hepatic copper toxicosis. Journal of Hepatology 38, 164-168.

Myers BM, Prendergast FG, Holman R, Kuntz SM \& LaRusso NF (1993) Alterations in hepatocyte lysosomes in experimental hepatic copper overload in rats. Gastroenterology 105, $1814-1823$.

Nakano A, Marks DL, Tietz PS, de Groen PC \& LaRusso NF (1995) Quantitative importance of biliary excretion to the turnover of hepatic lysosomal enzymes. Hepatology 22, 262-266.

Nanji MS \& Cox DW (1999) The copper chaperone Atox1 in canine copper toxicosis in Bedlington terriers. Genomics 62, $108-112$.

Oude Elferink RO \& Groen AK (2002) Genetic defects in hepatobiliary transport. Biochimica et Biophysica Acta 1586, 129-145.

Payne AS \& Gitlin JD (1998) Functional expression of the Menkes disease protein reveals common biochemical mechanisms among the copper-transporting P-type ATPases. Journal of Biological Chemistry 273, 3765-3770.

Petris MJ, Smith K, Lee J \& Thiele DJ (2003) Copperstimulated endocytosis and degradation of the human copper transporter, hCtr1. Journal of Biological Chemistry 278, 9639-9646.

Petrukhin K, Fischer SG, Pirastu M, Tanzi RE, Chernov I, Devoto M et al. (1993) Mapping, cloning and genetic characterization of the region containing the Wilson disease gene. Nature Genetics 5, 338-343.

Pufahl RA, Singer CP, Peariso KL, Lin SJ, Schmidt PJ, Fahrni CJ, Culotta VC, Penner-Hahn JE \& O'Halloran TV (1997) Metal ion chaperone function of the soluble $\mathrm{Cu}(\mathrm{I})$ receptor Atx1. Science 278, 853-856.

Puig S, Lee J, Lau M \& Thiele DJ (2002) Biochemical and genetic analyses of yeast and human high affinity copper transporters suggest a conserved mechanism for copper uptake. Journal of Biological Chemistry 277, 26021-26030.

Roelofsen H, Wolters H, Van Luyn MJ, Miura N, Kuipers F \& Vonk RJ (2000) Copper-induced apical trafficking of ATP7B in polarized hepatoma cells provides a mechanism for biliary copper excretion. Gastroenterology 119, 782-793.

Su LC, Ravanshad S, Owen CA Jr, McCall JT, Zollman PE \& Hardy RM (1982) A comparison of copper-loading disease in Bedlington terriers and Wilson's disease in humans. American Journal of Physiology 243, G226-G230.
Tanner MS, Portmann B, Mowat AP, Williams R, Pandit AN, Mills CF \& Bremner I (1979) Increased hepatic copper concentration in Indian childhood cirrhosis. Lancet i, 1203-1205.

Tanzi RE, Petrukhin K, Chernov I, Pellequer JL, Wasco W, Ross B et al. (1993) The Wilson disease gene is a copper transporting ATPase with homology to the Menkes disease gene. Nature Genetics 5, 344-350.

Trauner M \& Boyer JL (2003) Bile salt transporters: molecular characterization, function, and regulation. Physiology Reviews 83, 633-671.

Uetz P, Giot L, Cagney G, Mansfield TA, Judson RS, Knight JR et al. (2000) A comprehensive analysis of protein-protein interactions in Saccharomyces cerevisiae. Nature 403, 623-627.

Vanderwerf SM, Cooper MJ, Stetsenko IV \& Lutsenko S (2001) Copper specifically regulates intracellular phosphorylation of the Wilson's disease protein, a human coppertransporting ATPase. Journal of Biological Chemistry 276, 36289-36294.

van de Sluis BJ, Breen M, Nanji M, van Wolferen M, de Jong P, Binns MM, Pearson PL, Kuipers J, Rothuizen J, Cox DW, Wijmenga C \& van Oost BA (1999) Genetic mapping of the copper toxicosis locus in Bedlington terriers to dog chromosome 10 , in a region syntenic to human chromosome region 2p13-p16. Human Molecular Genetics 8, 501-507.

van de Sluis B, Kole S, van Wolferen M, Holmes NG, Pearson PL, Rothuizen J, van Oost BA \& Wijmenga C (2000) Refined genetic and comparative physical mapping of the canine copper toxicosis locus. Mammalian Genome 11, 455-460.

van de Sluis B, Nanji MS, Breen M, Pearson PL, Oost BA, Cox DW \& Wijmenga C (2001) Characterization and chromosomal localization of five canine ATOX1 pseudogenes. Cytogenetics and Cell Genetics 93, 105-108.

van de Sluis B, Rothuizen J, Pearson PL, van Oost BA \& Wijmenga C (2002) Identification of a new copper metabolism gene by positional cloning in a purebred dog population. Human Molecular Genetics 11, 165-173.

Vrana KE, Freeman WM \& Aschner M (2003) Use of microarray technologies in toxicology research. Neurotoxicology 24, 321-332.

Vulpe C, Levinson B, Whitney S, Packman S \& Gitschier J (1993) Isolation of a candidate gene for Menkes disease and evidence that it encodes a copper-transporting ATPase. Nature Genetics 3, 7-13.

Walker JM, Tsivkovskii R \& Lutsenko S (2002) Metallochaperone Atox1 transfers copper to the NH2-terminal domain of the Wilson's disease protein and regulates its catalytic activity. Journal of Biological Chemistry 277, 27953-27959.

Waring JF \& Halbert DN (2002) The promise of toxicogenomics. Current Opinion of Molecular Therapy 4, 229-235.

Wernimont AK, Huffman DL, Lamb AL, O'Halloran TV \& Rosenzweig AC (2000) Structural basis for copper transfer by the metallochaperone for the Menkes/Wilson disease proteins. Nature Structural Biology 7, 766-771.

Yamaguchi Y, Heiny ME \& Gitlin JD (1993) Isolation and characterization of a human liver cDNA as a candidate gene for Wilson disease. Biochemical and Biophysical Research Communications 197, 271-277.

Yuzbasiyan-Gurkan V, Blanton SH, Cao Y, Ferguson P, Li J, Venta PJ \& Brewer GJ (1997) Linkage of a microsatellite marker to the canine copper toxicosis locus in Bedlington terriers. American Journal of Veterinary Research 58, 23-27.

Zhou B \& Gitschier J (1997) hCTR1: a human gene for copper uptake identified by complementation in yeast. Proceedings of the National Academy of Sciences USA 94, 7481-7486. 